\title{
The Adoption of Silvofishery System to Restore Mangrove Ecosystems and Its Impact on Farmers' Income in Mahakam Delta, Indonesia
}

\section{SUSIL0, Heru}

Laboratory of Environmental Economics, Department of Agricultural and Resource Economics, Faculty of Agriculture, Kyushu University | Department of Fisheries Socio-Economics, Faculty of Fisheries and Marine Science, Mulawarman University | Laboratory of Environmental

Economics, Department of Agricultural and Resource Economics, Faculty of Agriculture, Kyushu University

TAKAHASHI, Yoshifumi

Laboratory of Environmental Economics, Department of Agricultural and Resource Economics, Faculty of Agriculture, Kyushu University

SAT0, Goshi

Laboratory of Environmental Economics, Department of Agricultural and Resource Economics, Faculty of Agriculture, Kyushu University

NOMURA, Hisako

Attached Promotive Center for International Education and Research of Agriculture, Faculty of Agriculture, Kyushu University | Laboratory of Environmental Economics, Department of Agricultural and Resource Economics, Faculty of Agriculture, Kyushu University

他

https://doi.org/10.5109/1955666

出版情報：九州大学大学院農学研究院紀要. 63 (2)，pp.433-442，2018-09-01. Faculty of Agriculture, Kyushu University

バージョン：

権利関係 : 


\title{
The Adoption of Silvofishery System to Restore Mangrove Ecosystems and Its Impact on Farmers' Income in Mahakam Delta, Indonesia
}

\section{Heru SUSILO ${ }^{1,2}$, Yoshifumi TAKAHASHI, Goshi SATO, Hisako NOMURA ${ }^{3}$ and Mitsuyasu YABE*}

\author{
Laboratory of Environmental Economics, Department of Agricultural and Resource Economics,
} Faculty of Agriculture, Kyushu University, Fukuoka 819-0395, Japan

(Received May 1, 2018 and accepted May 8, 2018)

\begin{abstract}
To solve a severe issue on mangrove loss and to maintain farmer livelihood in Mahakam Delta, the silvofishery system adopted by farmers have been signed into the design and implementation of recovery management strategies for mangrove ecosystems of Indonesia. Previous studies show that the silvofishery system positively impacts the livelihood of coastal communities. This study evaluates the factors that affect farmers' decision to adopt the silvofishery system in the Mahakam Delta and investigates the causal impact of adoption to their income. Cross-section analysis of 284 farmers through face-to-face interviews from two sub-districts within the Mahakam Delta was used. A logit model to analyze the adoption determinant and the propensity score matching technique to determine the causal impact of the silvofishery system on farmers' income. A prominent feature of the study shows that in socio-economic characteristics, family size and residence status are key determinants of farmers' decision to adopt silvofishery. Also, social capital, the current mangrove condition and recognition of benefits from mangroves as nursery ground have a robust and significant positive impact on farmers' decision. The average treatment effect for the treated (ATT) after matching using single and five nearest neighbor matching (NNM) with replacement and common support displays a positive impact of silvofishery on annual income per hectare of farmers. This study demonstrates that focus on community involvement coupled with information dissemination, education, and communication about the importance of mangroves and the silvofishery system application in the Mahakam Delta mangrove ecosystem.
\end{abstract}

Key words: propensity score matching, silvofishery, income, Mahakam Delta

\section{INTRODUCTION}

The Asian shrimp aquaculture comprises a significant portion of the global shrimp supply. In 2011, $62 \%$ of global shrimp exports came from Asia. From 2011 to 2013, Asia contributed about 74\% of world shrimp capture, $85 \%$ of world farmed shrimp production, respectively (FAO, 2007; Portley, 2016). Indonesia, which is ranked second in world seafood production is a significant player in the global shrimp supply. In 2010 and 2011, Indonesia's average annual shrimp capture and farmed shrimp productions were 239,419 metric tons and 389,435 metric tons, respectively (FAO, 2015). At the time, it accounted for $8.8 \%$ of global shrimp production. More recently, the Marine and Data of Fisheries Statistics Indonesia (2015), estimated that the total national output of shrimp in 2014 is 912,502 tons derived from 639,369 tons of farmed production and 273,133 tons of shrimp capture production. For shrimp exports, Indonesia produced 162,580 tons in 2014, valued at US $\$ 1.39$ billion. The growth average for volume and value of Indonesian shrimp exports from 2010 to

\footnotetext{
1 Laboratory of Environmental Economics, Department of Agricultural and Resource Economics, Faculty of Agriculture, Kyushu University, Japan

Department of Fisheries Socio-Economics, Faculty of Fisheries and Marine Science, Mulawarman University, Indonesia

Attached Promotive Center for International Education and Research of Agriculture, Faculty of Agriculture, Kyushu University, Fukuoka, Japan

* Corresponding author (E-mail: yabe@agr.kyushu-u.ac.jp)
}

2014 is $8.19 \%$ and $19.95 \%$, respectively. The United States and Japan are the significant importers of Indonesia's shrimp, accounting for $50 \%$ and $20 \%$ of total exports, respectively.

The importance of shrimp farms in Indonesia's aquaculture has become a compelling alternative for export earnings and rural coastal livelihood. According to the Marine and Fisheries Statistics Indonesia (2015), Indonesia's brackish water pond potential is more than 2 million ha with a usage area of only $22.50 \%$, and the number of households is 247.733 families. Therefore, aquaculture can contribute not only to the employment of coastal communities but also the national economy.

The accelerated growth of aquaculture as a result of high demand for global shrimp, however, disrupted many mangrove ecosystems, where the accelerated conversion of mangrove forests to brackish water pond occurs worldwide. Mangroves, which are found in 124 tropical and subtropical countries, are forest types that are salt-tolerant and found along coastlines, deltas, and estuaries (FAO, 2007). Mangroves provide biologically and economically crucial functions of goods and services mainly among communities situated in the coastal area. Mangroves contribute as breeding and nursery ground for aquatic organisms. They are also often used as wood and non-wood forest products by coastal communities. Mangrove forests protect coastal areas from tidal waves, hurricanes, and tsunamis as well as stabilize shorelines of the coastal zone. They also help in sequestering carbon in the atmosphere, where about 22.8 million metric tons of carbon is sequestered 
annually by mangrove forests (Giri et al., 2011). About $20 \%$ of mangrove forests, however, have declined rapidly in the last 25 years by large-scale conversion to aquaculture, settlements, and overexploitation (Primavera, 1997; Giri et al., 2011; Spalding et al., 2010). Asia has the highest diversity and most significant area of mangroves in the world. Some $42 \%$ of the global mangroves and more than 50 mangrove species are found in this region. According to FAO (2007), about 1.9 million hectares of Asian mangrove forests were converted into other land uses from 1980 to 1990. This has resulted in a substantial net loss for in mangrove forest cover in the world.

About $22.6 \%$ of global mangroves is located in Indonesia. It currently has 3.1 million hectares of mangroves and 45 out of 75 identified species of mangroves (Spalding et al., 2010; Giri et al., 2011). Unfortunately, Indonesian mangroves, have also been continually declining because of unplanned coastal development including conversion to extensive shrimp ponds. Ilman et al. (2016) reported that from 1800 to 2012, the degradation of mangrove forests is around 1 million hectares.

East Kalimantan Province is the second-largest area of mangrove forests in Indonesia, covering more than 364 thousand hectares or over $11 \%$ of the country's total mangrove area. The mangrove ecosystem in this province has played a crucial role in contributing to the ecological benefits for local communities, primarily direct-use values such as fishing, aquaculture, and fuelwood use (Susilo et al., 2017b). One of East Kalimantan's mangrove areas is the Mahakam Delta. The Mahakam Delta has a unique fan-shape and consists of 46 small islands that have been formed by the deposition of suspended solids over time (Sidik, 2009). In the 1950s, the expanse of mangrove as the original vegetation dominated this area with a total area of 106 thousand hectares (Bourgeois et al., 2002). At the time, Nypa was the most prominent mangrove species covering $55 \%$ of the entire region and the most significant pure Nypa vegetation site in the world (Creocean, 2000). However, the continuous degradation of mangrove forests in this delta has reduced mangrove coverage to around 29 thousand hectares. From 1992 to 2009, there was a $72 \%$ decrease in the mangrove area (Susilo et al., 2017a).

As a result, the Indonesian government has taken steps to design and implement programs directed towards the recovery and management of its mangrove ecosystems. Integrated mangrove-shrimp farming, also called silvofishery, is one of the strategies promoted by the government to combine the economic needs of coastal communities and conserve mangrove resources. Silvofishery, which is locally known as wanamina, is a form of integrated coastal farming system that combines brackish water aquaculture with mangrove conservation. It was first implemented in Indonesia in 1978 through a national cooperation program in research and has since been actively promoted by the Ministry of Environment and Forestry (MEF), the Ministry of
Marine Affairs and Fisheries (MMF), and academic institutions (Fitzgerald, 1999). After 20 years, the silvofishery model has been implemented across several regions by local government units (Takashima, 1999).

Silvofishery is a sustainable alternative to shrimp pond development without compromising the for the economic welfare of farmers and at the same time support conservation efforts of mangrove ecosystems. This issue is firmly related to sustainable development and to diminish inherent conflicts between shrimp pond development and mangrove conservation. The benefits from silvofishery in Indonesia is well-documented (e.g., Sukardjo, 1999; Takashima, 1999). Moreover, previous studies on aquaculture development in Mahakam Delta also give encouraging evidence for development (e.g., Bosma et al., 2012; Bunting et al., 2013; Rahman et al., 2013; Fauzi et al., 2013). However, the silvofishery system still hasn't gained a favorable reception from local communities, mainly farmers in the Mahakam Delta. Silvofishery lack of popularity is related to lack of education, behavior that even comfortable with old system or extensive aquaculture system, and disbelief that the new system will increase their income. There is a disparity in information and knowledge to the extent of silvofishery' power to improve the welfare of small-scale farmers and how this system affects farmers' income in the study area. Therefore, appraisal of the feasibility of the silvofishery adoption regarding the income of farmers is required.

As explained above, this study will focus on silvofishery system adoption and its impact toward the income of small-scale farmers. We also determined the primary driving factors that affect farmers' approval of the silvofishery scheme. The results provide useful insights for countries, especially developing countries to overcome the conflict between the livelihoods of local communities and ecology conservation. Also, the study contributes to the literature on the impact of adoption of the silvofishery farming system on small-scale farmer welfare in the Mahakam Delta.

\section{METHODS AND DATA COLLECTION}

\section{Analytical framework}

Adoption decision

We employ logit model to analyze the factors influencing the farmer' decision to adopt the silvofishery system. We assume that farmer will select to adopt the silvofishery only if the expected net benefits from adoption are positive and vice versa. The adoption benefits include improving farmers' income. The logit model can be written as follows:

$$
U_{i}^{*}=\beta_{i} X_{i}+\mu_{1}
$$

Where $U_{i}^{*}$ is a laten variable reflecting the net benefit of adopting the silvofishery, $\beta_{i}$ is the vector of logistic regression coefficients, $X_{i}$ is the vector of $I$ explanatory variables, and $\mu_{1}$ is the error term. As $U_{i}^{*}$ is not observable, then: 


$$
U_{i}= \begin{cases}1 & \text { if } U_{i}^{*}>0 \\ 0 & \text { if } U_{i}^{*} \leq 0\end{cases}
$$

Where $U_{i}$ represents that farmer will adopt the silvofishery system $\left(U_{i}=1\right)$ only if the net benefits from adoption are positive $\left(U_{i}^{*}>0\right)$. Otherwise, farmer will not adopt $\left(U_{i}=0\right)$ if the net benefits are non-positive.

\section{Propensity score matching (PSM)}

Since cross-sectional data was used, the effect of adoption could be estimated by differentiating outcome of adoption and non-adoption directly. These estimates, however, may be ambiguous and biased when counterfactual information is not available (Abid et al., 2016). The issue of self-selection bias becomes essential when calculating the net impact of adoption on farmer' income. For a non-randomized design, the PSM is one of several econometric approaches to solve the problem of selection bias. The PSM is a form of causal inference to design a balanced sample between the treatment (silvofishery adoption) and control (nonadaption) groups based on propensity scores. The propensity score is characterized as the conditional probability of receiving adoption or treatment (Rosenbaum and Rubin, 1983). The inference of silvofishery adoption impact is reasonable when comparing two farmer groups with identical observable characteristics. Following Rosenbaum and Rubin (1983), the PSM is implied the conditional probability that a farmer adopts the silvofishery, given pre-adaptation characteristics.

The PSM applies the conditional independence assumption (CIA) to create a statistical comparison group by matching both groups of adopters and nonadopters according to on the similarity of predicted probabilities of adopting the silvofishery ( $p$-score). The CIA can be represented as:

$$
\left(Y_{0}, Y_{1}\right) \perp U \mid \boldsymbol{X}
$$

The CIA states that for the set of observed covariates $\boldsymbol{X}$ is independent of possible outcomes. In other words, the participation in the adopting program is considered that does not depend on results, when the variation in findings created by differences in $\boldsymbol{X}$ has been controlled. This assumption states that the counterfactual income indicator in the adopted group is the same as the observed income for the non-adopted group. Then, the PSM as the first step can be denoted as:

$$
P\left(X_{i}\right)=\operatorname{Pr}\left(U_{i}=1 \mid X_{i}\right)<1
$$

Where $P$ indicates the propensity scores of preadoption characteristics $\left(X_{i}\right), U_{i}=\{0,1\}$ shows an indicator for adoption, and Pris the probability. The conditional distribution of $X_{i}$, given $P\left(X_{i}\right)$ is similar in both groups. In this study, logit regression is used as the first step to determine the propensity score for estimating the likelihood of adopting the silvofishery system.

The second step of PSM is to determine average treatment effect on the treated (ATT) to estimate the impact of adoption on income variable. To identify the
ATT, let we start to define the treatment effect (TE) following Rosenbaum and Rubin (1983) as the difference between the outcomes of farmers who adopted the silvofishery system and that the results of farmers who did not adopt the silvofishery system. It can be estimated as follows:

$$
\tau_{T E}=Y_{1}-Y_{0}
$$

In which $Y_{1}$ and $Y_{0}$ are, respectively, the outcome variables of farmers for adopters and non-adopters. Furthermore, the Average Treatment Effect (ATE) is computed to determine the effect of silvofishery adoption on farmer income. The ATE can be expressed as follows:

$$
\tau_{A T E}=E\left(Y_{1}-Y_{0}\right)
$$

ATE shows the average difference between the outcome of adopters and non-adopters. It also represents the overall impact of adoption on the outcome variables referring all farmers as respondents. As noted by Cameron and Trivedi (2005), the ATE proportion will be applicable if the adoption has universal application. Therefore, considering the hypothetical gain of adopting a randomly selected member of the population is feasible. In this study, because the respondent of silvofishery adoption is not chosen randomly, we employ the Average Treatment on Treated (ATT) to estimate the effect of silvofishery adoption on those who have adopted silvofishery. It can be written as follows:

$$
\begin{aligned}
\tau_{A T T} & =E\left(Y_{1}-Y_{0} \mid D=1\right) \\
& =E\left(Y_{1} \mid D=1\right)-E\left(Y_{0} \mid D=1\right)
\end{aligned}
$$

Where $D=1$ denotes a farmer as adopter and $D=0$ indicates a farmer as non-adopter. Although we can determine $\mathrm{E}\left(Y_{1} / D=1\right)$, we cannot observe $\mathrm{E}\left(Y_{0} / D=1\right)$ because it is the outcome farmer would have experienced if they had not been involved. Therefore, the CIA as explained in Equation (3) is an essential assumption underlying the PSM method. If the CIA is fulfilled, ATT can then redefined as:

$$
\begin{aligned}
\tau_{A T T} & =E\left(Y_{1}-Y_{0} \mid D=1\right) \\
& =E\left(Y_{1} \mid D=1, \boldsymbol{X}\right)-E\left(Y_{0} \mid D=0, \boldsymbol{X}\right)
\end{aligned}
$$

In the PSM, we use propensity score as explained in Equation (4) to match identical individuals. Rosenbaum and Rubin (1983) defined the propensity score $P(\boldsymbol{X})$ as the conditional probability of accepting treatment given the observed covariates $\boldsymbol{X}$. In this study, the logit model is used to determine the propensity score for estimating the likelihood of adopting the silvofishery system. The mean difference in outcomes between the adopting group and the control group under the CIA can then be estimated as follows:

$$
\tau_{A T T}^{P S M}=E\left(Y_{1} \mid D=1, \boldsymbol{P}(\boldsymbol{X})\right)-E\left(Y_{0} \mid D=0, P(\boldsymbol{X})\right)
$$


The assumption is that government has been implementing the silvofishery since 1970: farmers did not know that the adoption can increase the income: silvofishery was randomly adopted.

The results of the ATT $\left(\tau_{A T T}^{P S M}\right)$ are presented based on the matching technique which is Nearest Neighbor Matching (NNM) as the third step. The NNM is the easiest matching estimator that selects individuals from the comparison group as matching partner for adopted individuals that are closest regarding the propensity score (Caliendo and Kopeinig, 2008). Various literature explained several variants of the NNM, including NNM 'with replacement' and 'without replacement'. Caliendo and Kopeinig (2008) described that NNM 'with replacement' referred an untreated individual as a match can be used more than once, while NNM 'without replacement' is only once. In NNM 'with replacement', matching covers a trade-off between bias and variance, where there is an increase in the average quality of matching and the bias decreases. By replacement, use of the distinct number of nonparticipants to arrange the counterfactual outcome will reduce and thereby the variance of the estimator will increase (Smith and Todd, 2005). In this study, we apply the single and five NNM with replacement and common support to matching. Finally, estimation of the whole empirical analysis was carried out using the STATA software package.

\section{Study area}

The Mahakam Delta is one portion of the Kutai Kartanegara Regency in East Kalimantan Province. This delta, positioned along the eastern coast of Kalimantan Island, is between $117^{\circ} 15^{\prime}-117^{\circ} 40^{\prime} \mathrm{E}$ and $0^{\circ} 19^{\prime}-0^{\circ} 55^{\prime} \mathrm{S}$. The Mahakam Delta is morphologically divided into predominantly subaerial delta-plain at $1800 \mathrm{~km}^{2}$ and approximately $2000 \mathrm{~km}^{2}$ of delta front platform and delta-front slope accumulations (Allen and Chambers, 1998). The population in the study area is 99,347 individuals with 31,241 head households. They spread over 20 villages with occupation as fishers and fish farmers.

As mentioned earlier, degradation of mangroves in the Mahakam Delta is alarming. Bourgeois et al. (2002) have identified the conversion of mangroves into large shrimp ponds in the Mahakam Delta as a driving force in the loss of mangroves. In 1992, the first shrimp ponds began to appear on Muara Pantuan village, one of the communities in the Mahakam Delta. The appearance of ponds was simultaneously followed by developing the settlement of migrant fishers. In this phase, the whole shrimp ponds account for only $3 \%$ of the entire Mahakam Delta, and the impact to ecosystems is still limited. In 1996, some land changes appeared. Nypa has begun to decline, but it still dominates $48 \%$ of the delta landscape. Shrimp ponds, however, have increased and comprise $14 \%$ of the total area, becoming the third dominant land cover in the Mahakam Delta. The most dramatic change in Mahakam Delta occurred in the 1999 phase. Shrimp ponds or the space of being prepared to pond opening have converted 36,000 hectares of Nypa in three years. About 3,700 hectares of dense Avicennia disappeared, and the clearing of a further 4,000 hectares of mixed Nypa and disperse Avicennia. Moreover, nearly 5,500 hectares of fresh-water mangroves were converted for the preparation of shrimp ponds. The culmination of land cover changes in the Mahakam Delta occurred in the 2001 phase. In this period, fresh-water mangrove and fresh-water forests were almost nonexistent. Shrimp ponds continue to increase reaching approximately $75 \%$ of the aggregate area, where 50,000 hectares comprise of productive ponds and 31,000 hectares contain ponds in preparation. In this phase, shrimp ponds have also converted about 7,000 hectares of Nypa.

\section{Data collection and survey structure}

Data collection was taken out from February to April in 2017 using face-to-face interviews. Respondents were selected from three villages with the highest number of farmers, namely: Tani Baru and Muara Pantuan under Anggana sub-district, and Salok Palai and Saliki which are currently under the jurisdiction of the Muara Badak sub-district. Of the 300 distributed questionnaires, 284 were completed. For this study, adopters are farmers who applied silvofishery system, while non-adopters are farmers who did not implement the silvofishery system. Table 1 summarizes the definition and type of variables used for analysis including socio-economic, social capital, and perception attributes.

\section{DATA CHARACTERISTICS}

\section{Descriptive statistics}

Table 2 presents a descriptive analysis of the respondents. Of the 284 samples, 94 respondents (33.10\%) are adopters, while 190 respondents (66.90\%) are non-adopters. The average age of respondents is 40.18 years old, and insignificant differences between adopters and non-adopters were observed. Table 2 also displays that the average family size is $2.67 \mathrm{mem}-$ bers and about $56 \%$ of farmers in the study area are the immigrants. The majority of respondents have a primary school education, which reflects their current occupation as fishermen. This type of work does not require a high educational background, and many in the Mahakam Delta become skillful fishermen through years of experience. Both respondents from the adopter and non-adopter group have a similar number of years of farming experience at 12.15 years and 2.59 years, respectively. As such, group differences between adopters and non-adopters for the average of farming experience are not statistically significant.

Information about the social capital of respondents is also shown in Table 2. It shows the differences in mean along several observed covariates between adopters and non-adopters. For instance, we found that more adopters have farmers' group membership than non-adopters do. Likewise, farmers who have attended an aquaculture training and had a higher number of vis- 
Table 1. Definition and type of the variables used

\begin{tabular}{|c|c|c|}
\hline Variable & Unit & Description \\
\hline \multicolumn{3}{|c|}{ Socio-economic attributes } \\
\hline Age & Year & The actual age of respondents \\
\hline Family size & Person & Number of family members \\
\hline Residence status & Dummy & 1 if the respondent is indigenous; 0 if immigrant \\
\hline Education & Ordered & $\begin{array}{l}1=\text { never } ; 2=\text { primary school; } 3=\text { secondary school } ; 4= \\
\text { high school; } 5=\text { university degree }\end{array}$ \\
\hline Experience & Year & Farmers experience in aquaculture \\
\hline Income & Million IDR & farmer income per hectare per year \\
\hline \multicolumn{2}{|c|}{ Social capital attributes } & The actual age of respondents \\
\hline Group member & Dummy & $\begin{array}{l}1 \text { if the farmer is a member of a farmers' group, } 0 \\
\text { otherwise }\end{array}$ \\
\hline Training & Dummy & $\begin{array}{l}1 \text { if farmers have attended the aquaculture training, } 0 \\
\text { otherwise }\end{array}$ \\
\hline Extension & Times & Number of visits of extension agent each year \\
\hline \multicolumn{3}{|c|}{ Perception attributes } \\
\hline Severe & Ordered & $\begin{array}{l}\text { Farmer' attitude on the impact of mangrove degradation: } \\
1=\text { completely not severe; } 2=\text { not severe; } 3 \text { = neither; } 4= \\
\text { severe; } 5 \text { = very severe. }\end{array}$ \\
\hline Nursery ground & Ordered & $\begin{array}{l}\text { Farmer' perception of mangrove benefits as nursery } \\
\text { ground for human being: } 1=\text { strongly disagree; } 2= \\
\text { disagree; } 3=\text { neither; } 4=\text { agree; } 5=\text { strongly agree. }\end{array}$ \\
\hline
\end{tabular}

Table 2. Descriptive statistic of respondents

\begin{tabular}{lrrrrrrrr}
\hline \multirow{2}{*}{ Variable } & \multicolumn{2}{c}{ All $(\mathrm{n}=284)$} & \multicolumn{3}{c}{ Adopters $(\mathrm{n}=94)$} & \multicolumn{2}{c}{$\begin{array}{c}\text { Non-adopters } \\
(\mathrm{n}=190)\end{array}$} & \multirow{2}{*}{ Differences } \\
\cline { 2 - 9 } & \multicolumn{2}{c}{ Mean } & Std. Dev & Mean & Std. Dev & Mean & Std. Dev & \\
\hline Age & 40.18 & 10.28 & 40.21 & 10.33 & 40.16 & 10.28 & 0.05 & \\
Family size & 2.67 & 1.37 & 2.93 & 1.35 & 2.55 & 1.37 & 0.38 & $* *$ \\
Residence status & 0.44 & 0.50 & 0.37 & 0.49 & 0.48 & 0.50 & -0.11 & $*$ \\
Education & 2.44 & 0.74 & 2.60 & 0.81 & 2.36 & 0.69 & 0.24 & $* *$ \\
Experience & 12.45 & 6.80 & 12.15 & 6.37 & 12.59 & 7.01 & -0.44 & \\
Group member & 0.08 & 0.27 & 0.17 & 0.38 & 0.04 & 0.19 & 0.13 & $* * *$ \\
Training & 0.50 & 0.50 & 0.74 & 0.44 & 0.38 & 0.49 & 0.36 & $* * *$ \\
Extension & 0.52 & 0.96 & 0.66 & 1.18 & 0.45 & 0.82 & 0.21 & $*$ \\
Severe & 3.85 & 0.50 & 3.90 & 0.47 & 3.83 & 0.51 & 0.07 & \\
Nursery ground & 3.78 & 0.64 & 3.96 & 0.53 & 3.69 & 0.67 & 0.27 & $* * *$ \\
\hline
\end{tabular}

Notes: *****, and *indicate significance level at 1\%, 5\%, and $10 \%$ respectively

its from an extension agent annually tend to belong to the adopter's group. This suggests that farmers who have more significant interaction with social groups through farmer group membership, training attendance, and regular contact with extension agents have greater insight and are likely to become adopters. Despite the low level of education of respondents, these activities became an informal venue to enhance farmer knowledge and improve their livelihood.

Respondents were asked to rate the current mangrove condition and their responses regarding the importance of mangroves as a nursery ground and its relationship to their farming activities (Table 2). A fivepoint Likert scale measuring the degree of their agreement was applied ranging from 1 = entirely not severe/ strongly disagree to $5=$ very severe/strongly agree. On average, respondents rated that the current condition of mangrove forests condition was severe. Most respondents also agreed that the benefits of mangroves as nursery ground provided a positive impact on their farming.

\section{Awareness and perceptions regarding mangrove benefits}

Respondents were asked to rate the current condition of mangrove forests and the benefits derived from mangroves as a nursery ground for their farms. Table 3 shows their responses using a five-level Likert scale. Results reveal that the majority (85.92\%) of respondents indicated that the current mangrove condition as "severe", and $1.76 \%$ provided the rating "very severe". Meanwhile, $4.23 \%$ of respondents indicate that the mangrove condition is "not severe, and the remaining 
23 of respondents indicate that the condition of mangroves is neither severe nor not severe. In addition, 227 (79.93\%) agreed that mangroves provided the benefits for their ponds as a nursery ground. The same number of respondents (8.45\%) disagreed and did not respond to this question.

\section{Pond characteristic and income by land size}

Farmers in the study area generally operate their ponds by traditional or extensive systems due to the availability of mangrove forest land for conversation. Silvofishery system was developed and promoted by the government and NGOs to reduce mangrove degradation because of extensive farming in the area. There are two types of silvofishery design found in the study area: (1) mangroves are maintained within ponds and around the dikes, and (2) mangroves are outside the ponds. The income generated by respondents based on their pond area is shown in Table 4. Results show that the majority of (47.18\%) farmers have ponds ranging from 5 to 10 hectares. The remaining $24.65 \%$ ( $\mathrm{n}=70$ ), $8.45 \%$ ( $n=24)$, and $8.45 \%(n=24)$ have ponds less than 5 hectares, 11 to 15 hectares, and 16 to 20 hectares, respectively. Thirty-two farmers (11.27\%) have ponds with dimensions greater than 20hectares. Farmers cultivate different types of seafood. Farmers cultivate tiger shrimp (Penaeus monodon) in 3 cycles per year, each period lasting 3 to 4 months. For milkfish (Chanos chanos), one cycle requires 6 to 8 months before harvest. In addition to tiger shrimp and milkfish, farmers also raise wild shrimp varieties such as the white shrimp ( $P$. indicus) and pink-T shrimp (Metapenaeus affinis), and native crabs (Scylla spp). Farmers collect their spawn for wild shrimp during the tidal exchange which allows shrimp to enter the pond. These are collected every 20 days or at each new moon. Respondent revenues from their harvest are shown in Table 4 . Results show that the average revenue of farmers whose pond size is greater than 20 hectares are the largest, with IDR 140.78 million (US $\$ 10.59$ thousand) per hectare per year, followed by 16 - 20 hectares with IDR 104.18 million (US $\$ 7.84$ thousand) per hectare annually.

The operational costs of farmers come from the purchase of tiger shrimp and milkfish seeds (also locally known as benur and nener), saponin, lime, and labor wages. Saponin is used to treat ponds before seed stocking to wipe out the threat from predators and competitors. Lime is used to reduce sediment and water acidity. Labor wage system is based on profit-sharing after total revenue less the operational cost with a ratio around 50:50 or 60:40 for labor. Farmers do not use the feed to grow tiger shrimp and milkfish. Farmers whose pond size is less than 5 hectares have the lowest annual operational cost, with IDR 26.91 million (US\$2.02 thousand) per hectare, while those with the highest operational expenditure are farmers with ponds more 20 hectares at IDR 94.05 million (US $\$ 7.07$ thousand) per hectare. Farmer income per hectare per year is thus IDR 19.38 million (US $\$ 1.46$ thousand) for ponds less than 5 hectares (lowest) and IDR 46.73 million (US $\$ 3.51$ thousand) for ponds measuring more than 20 hectares (highest).

\section{RESULTS AND DISCUSSION}

\section{Adoption model estimation results}

Table 5 presents results of the prediction of the silvofishery adoption using a logit model. In this model, the dependent variable is coded as 1 for silvofishery adopters and 0 for non-adopters. The estimated logit model is rated to be the proper fit of the model as the percentage correctly predicted is $76.76 \%$, and the value of the Likelihood Ratio-Chi-Square test (76.13) is significant at $1 \%$ level of significance. The estimated parameters indicate that the adoption among farmers is influenced by the socioeconomic characteristics, social capital and the perception of the current mangrove condition and mangrove benefits as nursery ground. Of

Table 3. Farmers rate the current mangrove condition and the benefits of mangroves as a nursery ground

\begin{tabular}{lccccc}
\hline \multicolumn{1}{r}{ Description } & ENS/SD & NS/D & N & S/A & VS/SA \\
\hline Severe & 0 & 12 & 23 & 244 & 5 \\
Mangrove benefits & 0 & 24 & 24 & 227 & 9 \\
\hline
\end{tabular}

Notes: $E N S=$ entirely not severe; $S D=$ Strongly disagree; $N S=$ Not severe $; D=$ Disagree; $N=$ Neither; $S=$ Severe; $A=$ Agree $;$ VS = Very severe SA = Strongly Agree

Table 4. Income of farmer by land size

\begin{tabular}{lrrrrr}
\hline \multicolumn{1}{c}{ Variables } & \multicolumn{4}{c}{ Pond Area (ha) } \\
\cline { 2 - 5 } & \multicolumn{1}{c}{$<5$} & $5-10$ & $11-15$ & $16-20$ & $>20$ \\
\hline Revenue (IDR Million/year) & 46.29 & 76.49 & 86.47 & 104.18 & 140.78 \\
Operational cost (IDR Million/year) & 26.91 & 45.84 & 54.07 & 68.07 & 94.05 \\
Income (IDR Million/year) & 19.38 & 30.65 & 32.40 & 36.11 & 46.73 \\
Farmers (persons) & 70 & 134 & 24 & 32 \\
\hline
\end{tabular}

Notes: 1 USD was equivalent to IDR 13,296 at the time of data collection. 
5 socioeconomic variables considered in the logit model, two variables affect the silvofishery adoption. Based on collected results, family size and residence status variables are statistically significant at $10 \%$ and have positive and negative coefficients, respectively. Based on the obtained results, for family size, it indicates that farmers with larger family size want to adopt the silvofishery than farmers that have relatively smaller family size. Because pond farming is a labor-intensive action that requires labors, then, the larger sized household is the source of family labor that could contribute the cheap labor for adopting and implementing the silvofishery system. By selecting this system, moreover, farmers desire to have a sense of security in retirement by passing on the pond to their members of the household as the successor. Contrary, the result of residence status expresses that indigenous expects to accept considerably higher silvofishery than immigrant does.

All variables of social capital are positively related to the likelihood of a farmer adopting silvofishery. The estimated coefficients for group and extension are considerable at $1 \%$. Meanwhile, training variable is significant at 5\%. Results indicate that farmers who have involvement with a farmer's group and have attended the aquaculture training actively want to adopt the silvofishery as compared to respondents who are not members of a farmer group and who has not attended an aquaculture training. Because farmers in the study area have only lower formal education background, farmers who involved in a farmer's group and the aquaculture training obtained the informal knowledge and sharing insight that helped them to increase the skill and the ability to understand and appraised the silvofishery system adoption. Attained information provides the benefits for farmers to increase the productivity and income as well as contributing to the conserva- tion of mangroves. Also, the number of visits of an extension agent annually has significant effects on respondents' decision to adopt silvofishery. On respondents' responses about the current mangrove forest condition (severe variable) and mangrove functions (benefit variable), results indicate that silvofishery adoption among farmers is statistically significant at $10 \%$ and have a positive coefficient with their opinion on the severity of mangrove condition in the study area. Moreover, nursery ground variable also significantly effects the silvofishery adoption at $1 \%$ and has a positive coefficient. This finding implies that if farmers' attitude and knowledge of mangrove benefits on the severeness of mangrove degradation are enhanced, they are likely willing to adopt the silvofishery system. In particular, if farmers' awareness on the impact of mangrove loss is raised and agree that the damage would also affect their livelihood, they will appreciate more value for the existence of mangrove and adopt a more environmentally friendly farming system.

The results of marginal effect also appear in Table 5. The marginal effect of family size shows that increase by one member also increases the probability of a farmer to adopt the silvofishery system by $5 \%$. However, the result of residence status is contradictory when a farmer who adopts the silvofishery is immigrant, then the probability of adoption decreases by $11 \%$. Similarly, the marginal effect for group and training variables show a farmer who is involved in a farmer's group and attended the aquaculture training will increase the probability of adoption to $27 \%$ and $36 \%$, respectively. Also, the marginal effect of extension variable shows that when extension agents have visited a farmer, the probability of adoption increases by $8 \%$. These findings indicate that the farmer organization, practice, and extension services in the study area contribute to

Table 5. Logit estimation results of factors determining silvofishery adoption

\begin{tabular}{|c|c|c|c|c|c|}
\hline Variables & \multicolumn{2}{|c|}{ Coef. } & Std, Err. & z-value & Marginal Effects \\
\hline Age & -0.01 & & 0.02 & -0.70 & -0.01 \\
\hline Family size & 0.26 & $*$ & 0.14 & 1.86 & 0.05 \\
\hline Residence status & -0.54 & $*$ & 0.30 & -1.79 & -0.11 \\
\hline Education & 0.30 & & 0.20 & 1.51 & 0.06 \\
\hline Experience & -0.03 & & 0.03 & -1.13 & -0.01 \\
\hline Group & 1.35 & $* *$ & 0.55 & 2.44 & 0.27 \\
\hline Training & 1.75 & $* * *$ & 0.32 & 5.56 & 0.36 \\
\hline Extension & 0.38 & $* *$ & 0.17 & 2.24 & 0.08 \\
\hline Severe & 0.59 & $*$ & 0.33 & 1.78 & 0.12 \\
\hline Nursery ground & 0.82 & $* * *$ & 0.31 & 2.68 & 0.17 \\
\hline Constant & -7.72 & $* * *$ & 1.97 & -3.93 & \\
\hline Log-likelihood & -142.24 & & & & \\
\hline $\mathrm{LR} \mathrm{Chi}^{2}$ & 76.13 & $* * *$ & & & \\
\hline Pseudo $\mathrm{R}^{2}$ & 0.21 & & & & \\
\hline$\%$ predicted correctly & 76.76 & & & & \\
\hline Observations & 284 & & & & \\
\hline
\end{tabular}

Notes: *****, and * indicate significance level at 1\%, 5\%, and $10 \%$ respectively. 
Table 6. Test of matching quality indicator

\begin{tabular}{lcccrrr}
\hline \multirow{2}{*}{ Matching Method } & \multicolumn{2}{c}{ Pseudo ${ }^{2}$} & \multicolumn{2}{c}{ LR chi $^{2}$ (p-value) } & $\begin{array}{r}\text { Mean standardized } \\
\text { bias after matching }\end{array}$ \\
\cline { 2 - 6 } & \multicolumn{2}{c}{ Before } & After & Before & After \\
\hline $\mathrm{NNM}^{\mathrm{a}}$ & 0.21 & 0.06 & 76.13 & $* * *$ & 15.23 & 11.9 \\
$\mathrm{NNM}^{\mathrm{b}}$ & 0.21 & 0.03 & 76.13 & $* * *$ & 7.64 & 9.3 \\
\hline
\end{tabular}

Notes: $N N M^{a}=$ single $N N M$ with replacement and common support, $N N M^{b}=$ five $N N M$ with replacement and common support

1 USD was equivalent to IDR 13,296 at the time of data collection.

Table 7. The average treatment effect of silvofishery adoption

\begin{tabular}{cccccccccc}
\hline \multirow{3}{*}{ Outcome } & Matching & \multicolumn{4}{c}{ ATT } & \multicolumn{4}{c}{ ATU } \\
\cline { 3 - 9 } & Method & Adopter & $\begin{array}{c}\text { Non- } \\
\text { adopter }\end{array}$ & Dif. & Adopter $\begin{array}{c}\text { Non- } \\
\text { adopter }\end{array}$ & Dif. \\
\hline \multirow{2}{*}{ Income } & $\mathrm{NMN}^{\mathrm{a}}$ & 5.23 & 4.13 & 1.10 & $* * *$ & 4.68 & 3.93 & 0.75 & $* * *$ \\
& $\mathrm{NMN}^{\mathrm{b}}$ & 5.23 & 4.19 & 1.04 & $* *$ & 5.38 & 3.93 & 1.45 & $* *$ \\
\hline
\end{tabular}

Notes: Average treatment effects on the treated (ATT) and the untreated (ATU)

1 USD was equivalent to IDR 13,296 at the time of data collection.

increasing the likelihood of farmers to adopt silvofishery.

\section{Silvofishery adoption impact}

Before estimating the ATT, we test the indicators of the matching quality before and after matching from the nearest neighbor matching (NNM) using single and five NNM with replacement and common support. Table 6 shows that after randomization the standardized mean difference of the overall covariance lies between $9.3 \%$ and $11.9 \%$. Rosenbaum and Rubin (1985) suggested that below the critical level of $20 \%$ for the standardized mean difference was still proper. Results of the model goodness of fit are also presented in Table 6 . The value of pseudo $\mathrm{R}^{2}$ shows a decline from $21 \%$ before to $3 \%-6 \%$ after matching. Further, the corresponding $\mathrm{p}$-values for likelihood ratios present that a change from a statistically significant model to an insignificant model after matching. It displays that after matching the covariates are no more related to adaptation decisions. Also, the joint significance of covariates on adopter status could always be rejected after matching, where it was never denied before matching. Results after matching for the mean standardized bias, the pseudo $\mathrm{R}^{2}$ values, and insignificant $\mathrm{p}$-values in the likelihood ratio test depict that significant reduction in bias after matching was attained and the model is no more difference in the distribution of covariates between the two groups after matching. Thus, the specification of a model is acceptable, and that the primary assumption of 'selection on observables' is reliable.

As illustrated in equation (9), the ATT measures the outcome (income) between the silvofishery system adoption and non-adoption. The ATT after matching using single and five NNM with replacement and common support was presented in Table 7. Results display a positive impact of silvofishery on annual income per hectare of farmers, implying adopter system has increased the yearly earnings to between IDR 1.04 million (US\$78.22) per hectare and IDR 1.10 million (US\$ 82.73) per hectare. Results suggest that farmers of silvofishery made the right decision to adopt their shrimp pond system. These results are also in agreement with those obtained by Sukardjo (1999); Fitzgerald (1999); and Takashima (1999) who found that silvofishery has positive impacts on farmers' income in Indonesia. For non-adopters, their annual earnings would raise from IDR 3.93 million per hectare to in the range of IDR 0.75 million per hectare - IDR 1.45 million per hectare were they to adopt their shrimp pond to the silvofishery system. It indicates that silvofishery adoption was an appropriate decision for both groups.

\section{CONCLUSIONS}

This study shows that silvofishery system positively affects mangrove conservation and maintain a coastal livelihood in Indonesia. By assessing the impact of the silvofishery system on farmer income, we provide the basis for decision-makers to associate the driving factors of adaptation in the Mahakam Delta. The PSM method is implemented to determine the output of the adaptation process, with a model for selection bias according to observable differences for both adopter and non-adopter groups. Statistical results show that the primary assumptions used is acceptable and a causal interpretation of the conclusion is reliable.

The causal impact estimation of the PSM model reveals that the impact of silvofishery system adoption did have a significant influence on the income of farmers in the Mahakam Delta. Farmers who adopt silvofishery system can obtain higher earnings than those who did not choose to select it. A prominent characteristic of farmers' socio-demographic profile shows that family size and residence status are significant factors that 
influence the adoption decision. Moreover, social capital which includes membership to a farmer's group, attendance at an aquaculture training and extension services significantly affected farmer adoption and continued the practice of the silvofishery system. Farmer knowledge and awareness of mangrove forests' current condition and the benefits derived from their conservation have a positive influence on the adoption of an ecofriendly fish farming system.

These result findings must be elucidated to handle certain limitations and also provide insights for further studies. Firstly, although silvofishery system adoption can offer higher income than the non-silvofishery system, however, this adoption requires tight requirements. Silvofishery farmers who obtained higher income than non-adopters might already be well established and have more experience with this system. New farmers who want to switch to this system may have barriers associated with biophysics of land and water, mangrove vegetation suitability, carrying capacity, socioeconomic condition, and land ownership. It is a crucial finding that merits further studies by adding indicators to evaluate the effects of new system adoption to new farmers who want to switch to the silvofishery system such as biophysics land suitability and the engineering suitability of silvofishery. Further, integrated coastal zone planning and development is recommended to create harmony between conservation and economic interests and also mangrove damage can be controlled. The government also should contribute to monitoring, evaluation, and assistance related to aquaculture feasibility including technical, social, economic, and ecological aspects. Secondly, since cross-sectional data were used in this study, then it was not possible to assess the dynamic of farmer assets and evaluated the impact of silvofishery continuously and over time. Therefore, longitudinal researchers using time series data and integrated studies are recommended to estimate the longterm effects of silvofishery and its influence on all aspects. Also, due to this study has limitations where only uses income variable in the scope of impact estimation to estimate farmer welfare, then future studies could be considered by offering additional indicators of farmer welfare to evaluate the effects of silvofishery adoption. Despite this limitation, however, the findings provide some insight to help the decision-makers on the practical policy options available to promote ecofriendly adoption. The impact of silvofishery adoption showed a significant influence on the income of farmers and the determinants of adoption has recognized that socio-economic condition, social capital, and the awareness are driving forces for adopting.

From this results, we interpret that the silvofishery system adoption is a complementary solution to preserve mangrove ecosystems and improve farmer income in the Mahakam Delta. However, silvofishery is only a tool, and for it to continue work as a sustainable solution in the Mahakam Delta, the concerted effort of stakeholders and the government is critical. The role of the government, NGOs, private sectors, and universities are central in leading programs that empower farmer groups. These institutions can provide training on ecofriendly aquaculture and expand extension services to include environmental check, adequate pond construction, mangrove vegetation selection, commodity type, and marketing. Farmers are conscious of the current mangrove condition and recognized mangrove benefits as a nursery ground for fish and shrimp. Therefore, policy should focus on community involvement to conserve the environment. Also, the importance of mangroves and silvofishery system application should frequently be communicated thoroughly by agencies involved to increase awareness, demonstrate the effectiveness of silvofishery, gain farmers' trust in the program.

We recommend looking carefully at problems faced by farmers who have adopted the silvofishery system to retain their participation. For instance, fish or shrimp yields have been reported to decline when mangrove trees within the ponds reach 7-10 years of age due to lack of sunlight or shading effect of the forest canopy. In addition, mangrove leaves have a high tannin level that contaminates the water in ponds where substantial mangrove leaves fall and decompose. Due to the effect of these incidents in pond productivity, farmers commonly cut back mature mangrove trees within or around their ponds. Forcing farmers to retain mangroves that clearly affects their livelihood is a disincentive to the program. However, policy on cutting and replanting felled mangrove trees may be integrated with the current system to encourage farmers that mangrove forests and their ponds can co-exist. Wood from mature mangroves may be sold and could be an incentive for farmers who maintain mangrove trees and replant the ones they cut down. The government and the private sector can collaborate in designing an environmental incentives programs that focus on preserving mangrove trees within ponds and reducing operational cost for farmers.

\section{AUTHOR CONTRIBUTIONS}

Heru Susilo, Yoshifumi Takahashi, Goshi Sato, Hisako Nomura and Mitsuyasu Yabe conceived and designed the questionnaire; Heru Susilo performed the survey and data collection, analyzed the data and drafted the manuscript. Mitsuyasu Yabe and Yoshifumi Takahashi supervised and discussed the results of the study; and all the authors edited the earlier drafts, and approved the final version.

\section{ACKNOWLEDGMENTS}

The authors express their thanks to the respondents who participated in this study. Also, the authors thank the members of the Environmental Economics Laboratory at Kyushu University, Japan for their suggestions which contributed immensely to improve the quality of this paper. The assistance and contribution of the staff and students of the Department of Fisheries Socio-economics, Mulawarman University in Indonesia, 
and the Ministry of Research, Technology, and Higher Education of the Republic of Indonesia are also acknowledged.

\section{REFERENCES}

Abid, M., Schneider, U.A and Scheffran, J 2016 Adaptation to Climate Change and Its Impacts on Food Productivity and Crop Income: Perspectives of Farmers in Rural Pakistan. Journal of Rural Studies, 47: 254-266

Allen, G. P and Chambers, J.L.C 1998 Sedimentation in the Modern and Miocene Mahakam Delta, Indonesian. Petroleum Association, Jakarta, Indonesia

Bosma, R., Sidik, A. S., Zwieten, P. van., Aditya, A and Visser, L 2012 Challenges of A Transition to A Sustainably Managed Shrimp Culture Agro-ecosystem in The Mahakam Delta, East Kalimantan, Indonesia. Wetlands Ecology and Management, 20: 89-99

Bourgeois R.A., Gouyon A., Je'sus F., Levang P., Langeraar, W., Rahmadani F., Sudiono E and Sulistiadi, B 2002 A Socio Economic and Institutional Analysis of Mahakam Delta Stakeholders. Total-Fina-Elf, Belgium

Bunting, S. W., Bosma, R., Zwieten, P. van and Sidik, A. S 2013 Bioeconomic Modeling of Shrimp Aquaculture Strategies for The Mahakam Delta, Indonesia. Aquaculture Economics \& Management, 17: 51-70

Caliendo, M and Kopeinig, S 2008 Some Pratical Guidance for The Implementation of Propersity Score Matching. Journal of Economic Surveys, 22: 31-72

Cameron, A. C and Trivedi, P. K 2005 Microeconometrics: Methods and Applications. New York: Cambridge University Press

Creocean. 2000 Mahakam Delta 1999 Environmental Baseline Survey; Final Report to Total Indonesie; Creocean: Montpellier, France, 132p

FAO 2007 The World's Mangroves 1980-2005. FAO Forestry Paper 153. Rome, Italy: Food and Agricultural Organization

FAO 2015 Wild and Aquaculture Capture Production 19502013. FishStat J software and databases

Fauzi, A., Skidmore, A. K., Gils, H. Van, Schlerf, M and Heitkönig, I. M. A 2013 Shrimp Pond Effluent Dominates Foliar Nitrogen in Disturbed Mangroves as Mapped Using Hyperspectral Imagery. Marine Pollution Bulletin, 76: 42-51

Fitzgerald, W. J. J 1999 Integrated mangrove forest and aquaculture systems in Indonesia. In Proceedings of the MangroveFriendly Aquaculture Workshop,. Iloilo City, 11-14 Jan

Giri, C., Ochieng, E., Tieszen, L. L., Zhu, Z., Singh, A., Loveland, T., ... Duke, N 2011 Status and Distribution of Mangrove Forests of The World Using Earth Observation Satellite Data. Global Ecology and Biogeography, 20: 154-159

Ilman, M., Dargusch, P., Dart, P and Onrizal 2016 A Historical Analysis of The Drivers of Loss and Degradation of Indonesia's Mangroves. Land Use Policy, 54: 448-459

Marine and Fisheries Statistics Indonesia 2015 Kelautan dan Perikanan dalam Angka Tahun 2015 (Marine and Fisheries in Figures 2015)

Portley, N 2016 Report on the Shrimp Sector Asian Shrimp Trade and Sustainability. http://cmsdevelopment.sustainablefish.org.s3.amazonaws.com/2016/04/07/Asian\%20shrimp \%20summary\%20report-65b964a4.pdf accessed on 17-01-18

Primavera, J.H 1997 Socio-Economic Impacts of Shrimp Culture, Aquaculture Research, 28: 815-827

Rahman, A. F., Dragoni, D., Didan, K., Barreto-munoz, A and Hutabarat, J. A 2013 Detecting large scale conversion of mangroves to aquaculture with change point and mixed-pixel analyses of high-fi delity MODIS data. Remote Sensing of Environment, 130: 96-107

Rosenbaum, P. R and Rubin, D. B 1983 The Central Role of the Propensity Score in Observational Studies for Causal Effects. Biometrika, 70: 41-55

Rosenbaum, P. R and Rubin, D. B 1985 Constructing a Control Group Using Multivariate Matched Sampling Methods That Incorporate the Propensity Score. The American Statistician, 39: $33-38$

Sidik, A 2009 The changes of mangrove ecosystem in Mahakam Delta, Indonesia. A complex social-environmental pattern of linkages in resources utilization. Paper Presentation at Rescopar Scientific Meeting, Universitas Mulawarman. Samarinda, 25-26 February 2009., (November 2008), 25-29

Smith, J. A., Todd, P.E 2005 Does matching overcome LaLonde's critique of nonexperimental estimators? J. Econ. 125: 305-353

Spalding, M., Kainuma, M and Collins, L 2010 World atlas of mangroves. Earthscan, London, UK and Washington DC,USA., 39: $107-109$

Sukardjo, S 1999 Indonesia: mangrove-friendly aquaculture. In Proceedings of the Mangrove-Friendly Aquaculture Workshop. Iloilo City, 11-14 Jan

Susilo, H., Takahashi, Y and Yabe, M 2017a Evidence for Mangrove Restoration in the Mahakam Delta, Indonesia, Based on Households' Willingness to Pay. Journal of Agricultural Science, 9: 30-41

Susilo, H., Takahashi, Y and Yabe, M 2017b The Opportunity Cost of Labor for Valuing Mangrove Restoration in Mahakam Delta, Indonesia. Sustainability, 9: 1-13

Takashima, F 1999 Silvofishery : an aquaculture system harmonized with the environment. In Proceedings of the MangroveFriendly Aquaculture Workshop. Iloilo City, 11-14 Jan 